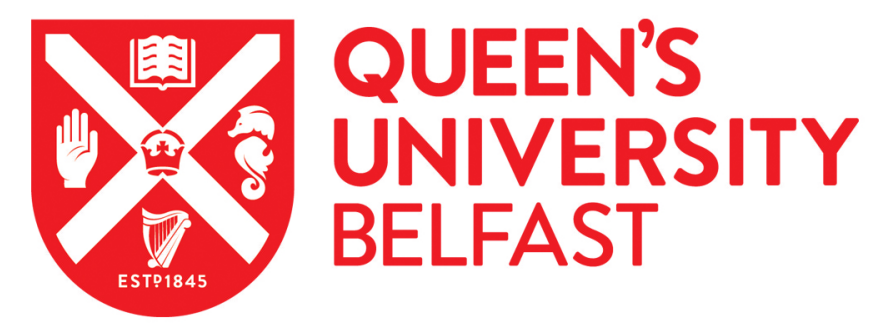

\title{
Distribution of the common lizard (Zootoca vivipara) and landscape favourability for the species in Northern Ireland
}

FarrenAodan, N. V., Prodöhl, P., Laming, P., \& Reid, N. (2010). Distribution of the common lizard (Zootoca vivipara) and landscape favourability for the species in Northern Ireland. Amphibia-Reptilia, 31(3), 387-387. https://doi.org/10.1163/156853810791769428

Published in:

Amphibia-Reptilia

Queen's University Belfast - Research Portal:

Link to publication record in Queen's University Belfast Research Portal

\section{General rights}

Copyright for the publications made accessible via the Queen's University Belfast Research Portal is retained by the author(s) and / or other copyright owners and it is a condition of accessing these publications that users recognise and abide by the legal requirements associated with these rights.

Take down policy

The Research Portal is Queen's institutional repository that provides access to Queen's research output. Every effort has been made to ensure that content in the Research Portal does not infringe any person's rights, or applicable UK laws. If you discover content in the Research Portal that you believe breaches copyright or violates any law, please contact openaccess@qub.ac.uk. 


\title{
Distribution of the common lizard (Zootoca vivipara) and landscape favourability for the species in Northern Ireland
}

\author{
Aodan Farren*, Paulo A. Prodöhl, Peter Laming, Neil Reid
}

\begin{abstract}
The common lizard (Zootoca vivipara) is Ireland's only native reptile, forming a key part of the island's biodiversity. However, there is a general paucity of distributional and abundance data for the species. In this study, we collated incidental records for common lizard sightings to define the distribution of the species in Northern Ireland. Maximum entropy modelling was employed to describe species-habitat associations. The resulting predicted landscape favourability was used to evaluate the current status of the species based on the distribution of its maximum potential range in relation to the degree of fragmentation of remaining suitable habitat. In common with previous studies in the Republic of Ireland, sightings were highly clustered indicating under-recording, observer bias, and fragmentation of suitable habitat. A total of 98 records were collated from 1905 to 2009 . The species was recorded in 63 (ca. 34\%) of $186 \times 10 \mathrm{~km}$ Northern Irish grid squares. Lizard occurrence was strongly and positively associated with landscapes dominated by heathland, bog and coastal habitats. The single best approximating model correctly classified the presence of lizards in $84.2 \%$ of cases. Upland heath, lowland raised bog and sand dune systems are all subject to Habitat Action Plans in Northern Ireland and are threatened by conversion to agriculture, afforestation, invasive species encroachment and infrastructural development. Consequently, remaining common lizard populations are likely to be small, isolated and highly fragmented. Establishment of an ecological network to preserve connectivity of remaining heath and bog will not only benefit remaining common lizard populations but biodiversity in general.
\end{abstract}

Keywords: biogeography, habitat suitability, Lacerta vivipara, maximum entropy, presence-only modelling, species occurrence.

\section{Introduction}

The common lizard (Zootoca vivipara) has one of the widest distributions of any reptile species, ranging throughout Europe and Asia as far north as the Arctic Circle including highlands up to $2000 \mathrm{~m}$ above sea level (Beebee and Griffiths, 2000). It is Ireland's only native reptile, forming a key part of the island's biodiversity and is protected in Northern Ireland under the Wildlife (NI) Order 1985. Despite its importance, however, relevant distributional and abundance data on the common lizard in Ireland is still lacking. One of main reasons for this has been the misreporting of common lizards as the smooth newt (Lissotriton vulgaris, formerly Triturus). There is also the general perception by the public that Ireland is devoid of such an 'exotic' species (Marnell, 2002; Meehan, 2007). An-

Quercus, School of Biological Sciences, Queen's University Belfast, MBC, 97 Lisburn Road, Belfast, Northern Ireland, BT9 7BL

*Corresponding author; e-mail: afarren02@qub.ac.uk other species of lizard, the slowworm (Anguis fragilis), also occurs in Ireland, but is restricted to the Burren, Co. Clare. It is not considered native since it was introduced from Great Britain during the 1970s (McGuire and Marnell, 2000).

In contrast to distributional data for the common lizard in Great Britain, which is based on incidental records and targeted surveys compiled at a county-level by a network of local Amphibian and Reptile Groups (ARGs), data for the species in Ireland are entirely incidental. Early distributional studies have suggested that the species was widespread with a largely coastal distribution but rarely occurring in significant numbers (Taylor, 1963; Ni Lamhna, 1979; Marnell, 2002; Meehan, 2007). Sightings are generally highly clustered, indicating that the species is under-recorded, underdispersed and confined to fragmented habitats or that sightings are biased towards those areas with greatest detectability, i.e., sites with high visitor frequency, for example, the Wicklow Mountains (fig. 1a). A common feature of 


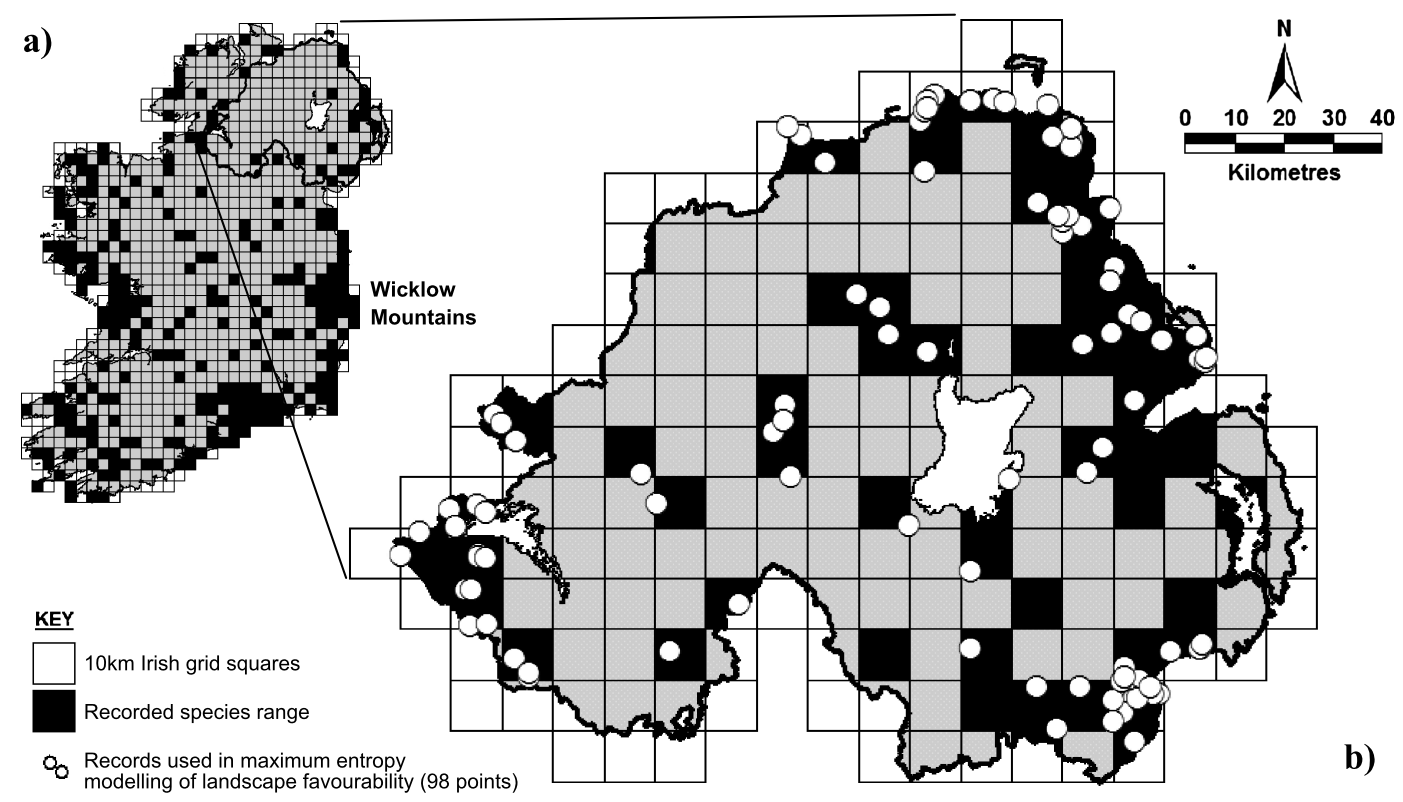

Figure 1. Common lizard distribution on a $10 \mathrm{~km}$ resolution in (a) Ireland from 1963 to 2002 (data were extracted from published maps in Taylor, 1963; Ni Lamhna, 1979; Marnell, 2002) showing high concentrations of records in the Wicklow Mountains and (b) Northern Ireland from 1905 to 2009 (black grids with open circles) plus the previous records (black grids without open circles).

previous studies was the lack of data for Northern Ireland. Whilst recent attempts have been made by the Irish Wildlife Trust (IWT) to coordinate data collection throughout the island, the available data remain largely biased towards the Republic of Ireland (Marnell, 2002; Meehan, 2007).

Unlike most reptiles, the common lizard frequents damp habitats such as bog and moor. Humidity has been shown to have a beneficial effect on growth rate and activity level for the species (Lorenzon et al., 1999). Due to its more northerly distribution, often associated with high altitudes, common lizards are particularly reliant on shelter and burrows, which offer protection against cold wet weather, facilitating thermoregulation and hibernation (Pilorge, 1987). Elsewhere, the habitat associations of the species are well known (Strijbosch, 1988). Marnell (2002) suggested that most lizard sightings in Ireland are associated with bog, heath and sand dunes whilst stone walls and rural gardens contributed significant numbers of sightings.
Here we collated incidental records of common lizard sightings to define the distribution of the species in Northern Ireland. Maximum entropy modelling was used to quantify the species' association with environmental parameters including habitat type, structure and altitude. The predicted probability of species occurrence was in turn, used to identify the species' potential range in relation to current remaining habitat.

\section{Materials and methods}

Species records

All records for the occurrence of common lizard sightings were collated from the Centre for Environmental Data and Recording (CEDaR) and National Biodiversity Network (NBN) Gateway, as well as solicited from the general public using local media. Only sightings with sufficient spatial resolution to identify a $1 \mathrm{~km}$ grid square (i.e. 4-figure grid reference) were used in analysis and plotted using ARCGIS ${ }^{\circledR}$ 9.3 (ERSI, California, USA). Species distribution was summarised at a $10 \mathrm{~km}$ spatial scale (i.e. 2-figure grid reference). A frequency histogram of sightings per month was constructed to examine the distribution of sightings throughout the year. 
Table 1. Environmental parameters included in landscape favourability modelling of common lizard occurrence (listed in alphabetical order).

\begin{tabular}{|c|c|c|c|}
\hline$\#$ & Explanatory variable(s) & Units & Description \\
\hline 1 & Acid grassland & Area & $\begin{array}{l}\text { Percentage of each } 1 \mathrm{~km} \text { square classed as semi-natural acid grassland calculated } \\
\text { from the UK LAND COVER MAP } 2000 \text { (LCM2000). }\end{array}$ \\
\hline 2 & Altitude & Metres & $\begin{array}{l}\text { Mean elevation above sea level of } 25 \mathrm{~m} \text { raster cells within } 1 \mathrm{~km} \text { squares of a Digital } \\
\text { Elevation Model (DEM) for Northern Ireland. }\end{array}$ \\
\hline 3 & Bareground & $\%$ & $\begin{array}{l}\text { Percentage of each } 1 \mathrm{~km} \text { square classed as bareground calculated from the UK LAND } \\
\text { COVER MAP } 2000 \text { (LCM2000). }\end{array}$ \\
\hline 4 & Bog & $\%$ & $\begin{array}{l}\text { Percentage of each } 1 \mathrm{~km} \text { square classed as bog, fen, marsh or swamp calculated from } \\
\text { the UK LAND COVER MAP } 2000 \text { (LCM2000). }\end{array}$ \\
\hline 5 & Bracken & $\%$ & $\begin{array}{l}\text { Percentage of each } 1 \mathrm{~km} \text { square classed as bracken calculated from the UK LAND } \\
\text { COVER MAP } 2000 \text { (LCM2000). }\end{array}$ \\
\hline 6 & Broad-leaved woodland & $\%$ & $\begin{array}{l}\text { Percentage of each } 1 \mathrm{~km} \text { square classed as broad-leaved or deciduous woodland } \\
\text { calculated from the UK LAND COVER MAP } 2000 \text { (LCM2000). }\end{array}$ \\
\hline 7 & Coastal habitats & $\%$ & $\begin{array}{l}\text { Percentage of each } 1 \mathrm{~km} \text { square classed as littoral rock, littoral sediment, supra- } \\
\text { littoral rock, supra-littoral sediment and saltmarsh calculated from the UK LAND } \\
\text { COVER MAP } 2000 \text { (LCM2000). }\end{array}$ \\
\hline 8 & Coniferous forest & $\%$ & $\begin{array}{l}\text { Percentage of each } 1 \mathrm{~km} \text { square classed as coniferous forest calculated from the UK } \\
\text { LAND COVER MAP } 2000 \text { (LCM2000). }\end{array}$ \\
\hline 9 & Habitat heterogeneity & Index & $\begin{array}{l}\text { Measure of habitat patch diversity, as defined by Shannon's Diversity Index, within } \\
\text { each } 1 \mathrm{~km} \text { square calculated using PATCH ANALYST } 4 \text { in ARCGIS 9.3. }\end{array}$ \\
\hline 10 & Heathland & $\%$ & $\begin{array}{l}\text { Percentage of each } 1 \mathrm{~km} \text { square classed as dwarf scrub heath or open dwarf scrub } \\
\text { heath calculated from the UK LAND COVER MAP } 2000 \text { (LCM2000). }\end{array}$ \\
\hline 12 & No. of habitat patches & $N$ & $\begin{array}{l}\text { Total number of discrete habitat patches within each } 1 \mathrm{~km} \text { square calculated using } \\
\text { PATCH ANALYST } 4 \text { in ARCGIS 9.3. }\end{array}$ \\
\hline
\end{tabular}

\section{Environmental parameters}

ARCGIS ${ }^{\circledR} 9.3$ was used to compute landscape scale habitat parameters from the UK LAND COVER MAP 2000 (Fuller et al., 2002). Environmental parameters were chosen intuitively based on landscape characteristics that were most likely to influence lizard occurrence (Strijbosch, 1988; Marnell, 2002; Meehan, 2007; table 1), and resampled to a common pixel size of $1 \mathrm{~km}$. Prior to biogeographical modelling of landscape favourability, predictor variables were tested for multicollinearity using ordinary least squares regression to ensure that all tolerance values were $>0.1$ and all variance inflation factor (VIF) values were $<10.0$ (Quinn and Keough, 2002). These indices are a measure of how much the variance of an estimated regression coefficient (the square of the estimate's standard deviation) is increased by collinearity between predictor variables. Tolerance values $>$ 0.1 and VIF values $>10$ indicate that multicollinearity is a problem (Quinn and Keough, 2002).

\section{Maximum entropy modelling}

A presence-only maximum entropy approach was chosen over more traditional presence-absence modelling techniques such as general linear modelling (GLM), general additive modelling (GAM) or boosted regression trees given increasing evidence in the literature supporting its greater predictive success, most notably at small sample sizes (Hernandez et al., 2006). Applying the maximum entropy algorithm to species distribution modelling aims to predict the unknown distribution of a species over a geographical region, from a sample set of known occurrences and spatially explicit environmental parameters. Estimation of the distribution of maximum entropy (nearing uniformity) is constrained by the distribution of expected values of environmental parameters matching their empirically observed mean (Phillips, Dudik and Schapire, 2004; Phillips, Anderson and Schapire, 2006). This is similar to Bayesian methods, which maximise the likelihood of the predicted probability of distribution given a priori information.

To maximise model flexibility, we considered linear, quadratic, product, threshold, hinged and discrete functions for all environmental parameters (Phillips and Dudík, 2008). Due to the paucity of lizard records it was not possible to partition the dataset into training and test sets. Jackknife resampling analysis was used to determine a heuristic estimate of the relative contribution of each variable based on the performance of the global model (known as \% gain) without the variable of interest compared to the influence of that variable in isolation (derived from a univariate model only). Global model performance was judged using the area under the receiver operating characteristic (ROC) curve (Liu et al., 2005).

Marginal response curves of the predicted probability of species occurrence were graphed for each explanatory variable that contributed $>8 \%$ variance to the global model. A 


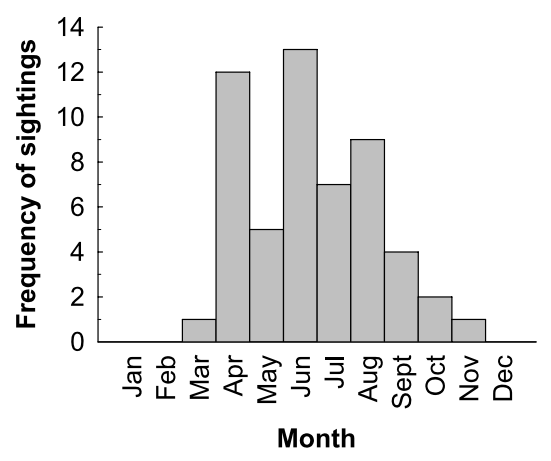

Figure 2. Frequency distribution of common lizard sightings throughout the year.

map of landscape favourability for the common lizard was generated to reflect the predicted probability of species occurrence and coloured in greyscale using five categories determined by natural break analysis in ARCGIS $9.3^{\circledR}$. All statistical analyses were performed using PSS v17 and Maxent 3.2.1 (Phillips, Anderson and Schapire, 2006; Phillips and Dudík, 2008).

\section{Results}

A total of 98 records were collated for common lizards in Northern Ireland from 1905 to 2009 (fig. 1b). Taken together with existing records, the species range included 63 (ca. 34\%) of $186 \times 10 \mathrm{~km}$ grid squares. Lizard records, whilst notably clustered, were widely distributed and came from all counties. The majority of sightings were recorded during summer (June-August) but April also had notable numbers (fig. 2).

Lizard occurrence was strongly and positively associated with landscapes dominated by heathland, coastal habitats and bog (figs 3 and 4). Lizards were also positively associated with altitude and coniferous plantations. Model performance, defined as the area under the curve or $\mathrm{AUC}=0.842$ indicating that lizard presence was correctly predicted in $84.2 \%$ of cases.

Predicted probabilities of species occurrence, taken as a measure of landscape favourability, suggested that whilst suitable habitat remains widely distributed it is nonetheless highly clustered (fig. 5). Large areas of suitable contiguous habitat exist in the uplands in the Sperrin

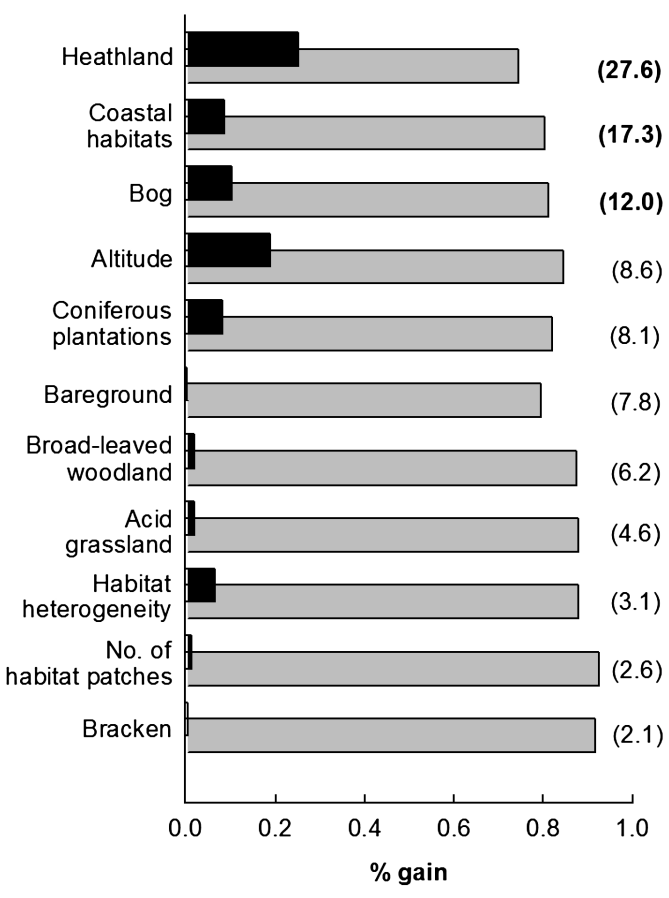

Figure 3. Jackknife analyses of the importance of environmental variables in maximum entropy modelling of common lizard distribution. A heuristic estimate of the relative contribution of each variable to the global model is given in parentheses whilst variables are listed in descending order of importance. Grey bars show the performance of the global model (known as test gain) without each variable and black bars show the influence of each variable in isolation (derived from a univariate model only).

Mountains, Mourne mountains, Antrim plateau, Slieve Beagh uplands and west Fermanagh. Favourable patches of suitable habitat in wider countryside in the lowlands were highly fragmented, including some coastal areas, such as Murlough National Nature Reserve (Co. Down) and the Magilligan-Umbra-Downhill sand dune complex (Co. Londonderry) or largely isolated patches, such as Peatlands Park (Co. Armagh).

\section{Discussion}

This is the first study to describe both the distribution of the common lizard, and the landscape favourability for the species in Northern Ireland. Lizards were widespread and sightings have been recorded in every county. In common 

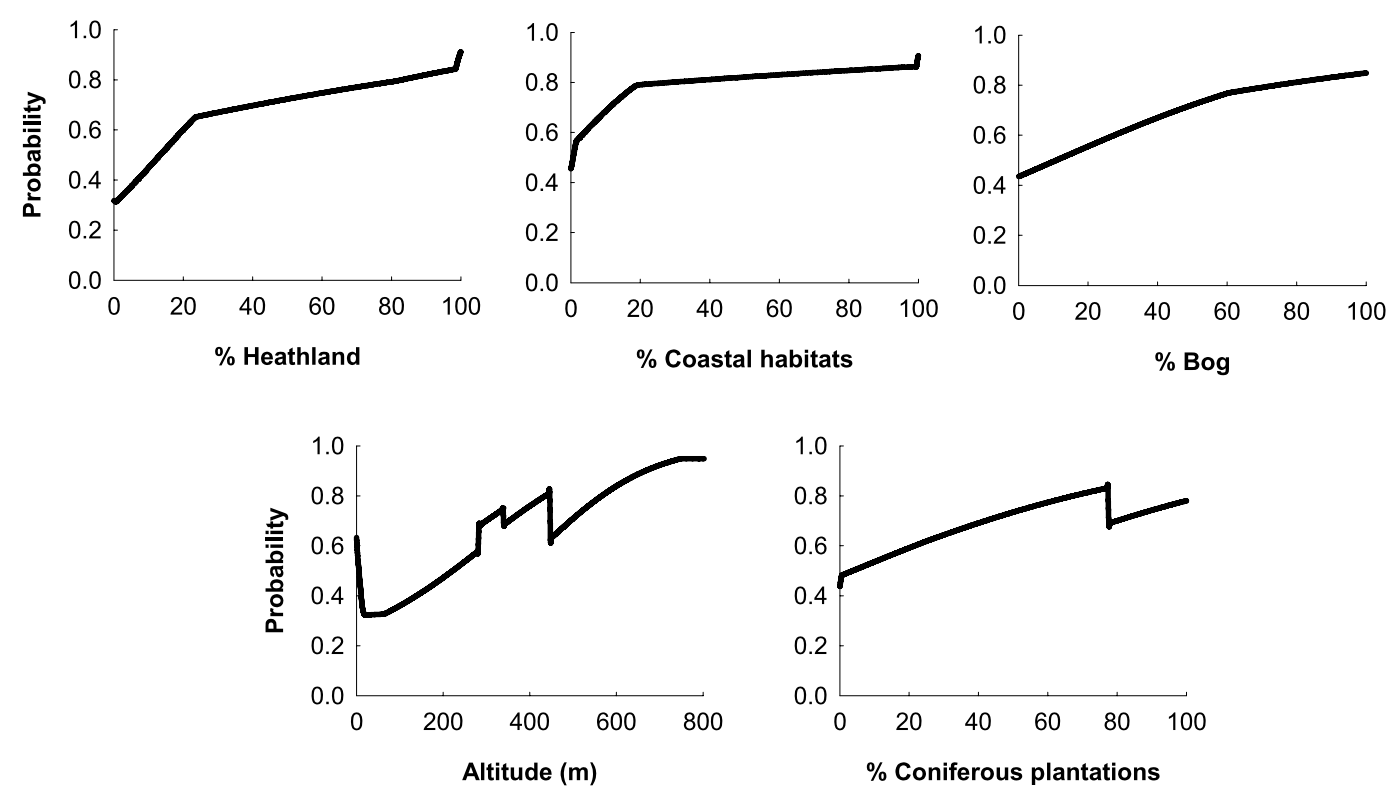

Figure 4. Marginal response curves of the predicted probability of common lizard occurrence for each explanatory variable that contributed $>8 \%$ variance to the global maximum entropy model. Curves show logistic predictions when all other environmental variables were maintained at their mean value.

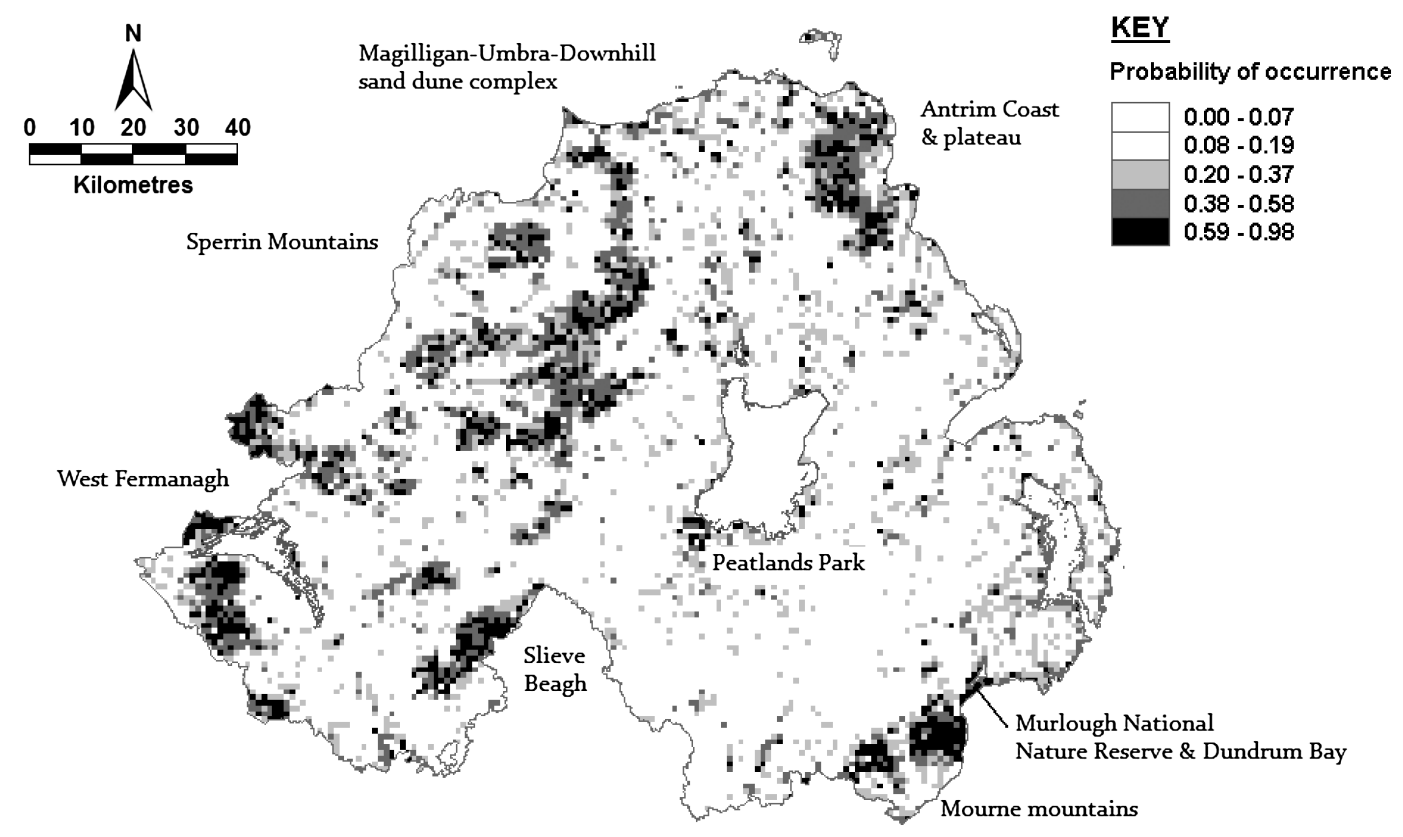

Figure 5. Biogeographical model of landscape favourability for common lizard occurrence in Northern Ireland. Categories of predicted probability of occurrence were chosen based on natural break analysis using ArcGIS 9.3. 
with previous studies from the Republic of Ireland (Taylor, 1963; Ni Lamhna, 1979; Marnell, 2002; Meehan, 2007), sightings were highly clustered indicating under-recording, observer bias and fragmentation of suitable habitat.

Marnell (2002) suggested that common lizard records are generally biased by popular summer destinations such as coastal or mountainous areas, for example, north Wicklow and Wexford. In Northern Ireland, sightings were also most frequent during summer and clustered in areas of high visitor frequency including the north Antrim Coast and the Mourne Mountains. The absence of sightings during the winter is not particularly surprising given that this coincides with the hibernation period, which occurs between October and March (Beebee and Griffiths, 2000). Whilst the landscape of the Sperrin Mountains was predicted as highly suitable for lizards, there were few sightings, suggesting lower recording effort due to low density human habitation, extensive farming and low visitor numbers.

Whilst the habitat associations of the species were well known elsewhere (Strijbosch, 1988) and in Ireland (Marnell, 2002; Meehan, 2007) quantifying relationships in Northern Ireland was necessary to construct a predictive model of landscape favourability. Lizards were strongly associated with heathland and bog, which provide an important source of invertebrate biodiversity for foraging (Usher, 1992; Bragg, 2002). Heath and bog are similar habitats with the former dominated by ericaceous plant communities with $>25 \%$ gorse (Ulex europaeus) and an open structure and the latter dominated by herbaceous and mossy vegetation. Both habitats are distinguished by their degree of groundwater saturation with bogs being significantly wetter, often with seasonal standing water. Nevertheless, both heath and bog offer a heterogeneous structure of heather-dominated vegetation providing lizards with shade and shelter, open areas for basking and raised areas of peat offering a fibrous burrow-rich matrix for shelter and hibernation. Coastal habitats, such as sand dunes provide open areas for basking, an abundance of invertebrate prey in suitably vegetated areas and thermally stable hibernacula.

The coverage of lowland raised bog in Northern Ireland has declined from 25000 ha to 2000 ha since the beginning of the nineteenth century due to exploitation for peat and turf and drainage for agricultural improvement (Anon, 2003a). Sand dune systems cover $<0.2 \%$ of Northern Ireland and are subject to a Habitat Action Plan (HAP) due to the threat from erosion caused by rising sea levels and increased human recreational use, over-grazing and encroachment of invasive species (Anon, 2005). Consequently, the greatest cover of remaining habitat suitable for lizards in Northern Ireland is restricted to the uplands. Remaining lowland populations occur predominately in coastal areas or in isolated patches of heath and bog, for example, Peatlands Park, Co. Armagh.

The common lizard has no difficulty in occupying the highest altitudes in Ireland as it is known up to $2000 \mathrm{~m}$ above sea level elsewhere, for example, the Pyrenees (Heulin, Osenegg and Michel, 1997; Beebee and Griffiths, 2000). Whilst altitude was an important predictive parameter in the current study, it may be that lizards were not associated with higher altitudes per se, just the habitats which now predominate the uplands. Heathland was the best predictor variable for lizard occurrence but was not collinear with altitude within the current sample of $98 \times 1 \mathrm{~km}$ grid squares. Nevertheless, it is highly likely that the occurrence of upland habitats has some relationship with altitude on a landscape scale, which may confound the true affect of altitude per se. For example, the Sperrins, Mournes, Antrim Plateau and western Fermanagh have approximately 58000 ha of upland heath and 5000 ha of lower altitude heath (Cooper and McCann, 2001). Upland heath is subject to a Habitat Action Plan due to the threat from conversion to agriculture, overgrazing, afforestation, burning, invasive species encroachment and infrastructural development such as the construction of quarries, wind farms 
and communication masts (Anon, 2003b). During 1988 , only $15 \%$ of the estimated 140000 ha of upland heath that remained in Northern Ireland was classified as intact; $85 \%$ had been drained, cutover for fuel or degraded in quality (Cruickshank and Tomlinson, 1988).

Common lizard dispersal distances are less than $100 \mathrm{~m}$ (Beebee and Griffiths, 2000) and unsuitable habitat can provide an effective barrier, making the species particularly vulnerable to population fragmentation (Boudjemadi, Lecomte and Clobert, 1999). In Northern Ireland, large contiguous populations are likely to remain in the uplands, but remaining lowland populations are almost certainly small, isolated and highly fragmented and thus, merit conservation concern. Inbreeding and loss of genetic diversity in small populations due to genetic drift can lead to a reduction in population fitness and hence long-term viability (Frankham, Ballou and Briscoe, 2004). Upland heath and lowland bog ecological networks may help preserve common lizard populations as well as biodiversity in general.

To increase distributional and abundance data for the common lizard in Northern Ireland targeted surveys incorporating line transects, pitfall traps and the deployment of attractants such as tin or felt sheets for basking are needed at sites where lizards are likely to occur. The landscape favourability model presented here provides an excellent basis on which to select potential survey sites. A 'Northern Ireland Lizard Survey' could concentrate on sites with the highest predicted values for landscape suitability, whilst specific sites could be monitored annually to obtain abundance data allowing interpretation of population temporal trends. Moreover, site-specific studies are required to elucidate small scale habitat selection, for example, examining the prevalence of hibernacula or looking at associations with invertebrate fauna communities.

Acknowledgements. We thank all those who provided lizard sightings and access to sites including the Ulster
Wildlife Trust (UWT), Forestry Service NI, National Trust, Northern Ireland Environment Agency (NIEA), Ministry of Defence (Magilligan), Belfast Zoo, M. Austin, J. Braniff and C. Montgomery. The primary author was supported by a Ph.D. studentship from the Department of Education and Learning (DEL) while NR was supported by the Natural Heritage Research Partnership (NHRP) between the Northern Ireland Environment Agency (NIEA) and Queen's University Belfast (QUB). The editor and two anonymous referees are thanked for their suggestions to improve the paper.

\section{References}

Anon (2003a): Northern Ireland Habitat Action Plan - Lowland Heathland. Northern Ireland Environment Agency. Available at http://www.ni-environment.gov.uk/ biodiversity/hap_uk/hap_ni.htm. Accessed online 03 August 2009.

Anon (2003b): Northern Ireland Habitat Action Plan - Lowland Heathland. Northern Ireland Environment Agency. Available at http://www.ni-environment.gov.uk/ biodiversity/hap_uk/hap_ni.htm. Accessed online 08 September 2009.

Anon (2005): Northern Ireland Habitat Action Plan - Coastal Sand Dunes. Northern Ireland Environment Agency. Available at http://www.ni-environment. gov.uk/biodiversity/hap_uk/hap_ni.htm. Accessed online 08 September 2009.

Beebee, T.J.C., Griffiths, R.A. (2000): Amphibians and Reptiles. London, HarperCollins.

Boudjemadi, K., Lecomte, J., Clobert, J. (1999): Influence of connectivity on demography and dispersal in two contrasting habitats: an experimental approach. J. Anim. Ecol. 68: 1207-1224.

Bragg, O.M. (2002): Hydrology of peat-forming wetlands in Scotland. Sci. Total Environ. 294: 111-129.

Cooper, A., McCann, T. (2001): Northern Ireland Countryside Survey 2000. Belfast, Environment and Heritage Service.

Cruickshank, M.M., Tomlinson, R.W. (1988): Northern Ireland Peatland Survey. Belfast, Department of the Environment for Northern Ireland (Countryside and Wildlife Branch).

Frankham, R., Ballou, J.D., Briscoe, D.A. (2004): Introduction to Conservation Genetics. Cambridge, Cambridge University Press.

Fuller, R.M., Smith, G.M., Sanderson, J.M., Hill, R.A., Thomson, A.G. (2002): The UK Land Cover Map 2000: Construction of a parcel-based vector map from satellite images. Cartogr. J. 39 (1): 15-25.

Hernandez, P.A., Graham, C.H., Master, L.L., Albert, D.L. (2006): The effect of sample size and species characteristics on performance of different species distribution modeling methods. Ecography 29: 773-785.

Heulin, B., Osenegg, K., Michel, D. (1997): Demography of a bimodal reproductive species of lizard ( $L a c$ erta vivipara): survival and density characteristics of oviparous populations. Herpetologica 53 (4): 432-444. 
Liu, C., Berry, P.M., Dawson, T.P., Pearson, R.G. (2005): Selecting thresholds of occurrence in the prediction of species distributions. Ecography 28 (3): 385-393.

Lorenzon, P., Clobert, J., Oppliger, A., John-Alder, H. (1999): Effect of water constraint on growth rate, activity and body temperature of yearling common lizard ( $\mathrm{Lac}$ erta vivipara). Oecologia 118: 423-430.

Marnell, F. (2002): The distribution and habitat of the common lizard, Lacerta vivipara Jacquin, in Ireland. Bull. Ir. Biogeog. Soc. 26: 75-82.

McGuire, C., Marnell, F. (2000): The present status of the slow-worm, Anguis fragilis L., in Ireland. Bull. Ir. Biogeog. Soc. 24: 69-74.

Meehan, S. (2007): The IWT National Survey of the Common Lizard (Lacerta vivipara) in Ireland 2007. Available at http://www.iwt.ie/J_pdf_downloads/ Lizard_Survey_2007.pdf. Accessed online 7th September 2009.

Ni Lamhna, E. (1979): Provisional Distribution Atlas of Amphibians, Reptiles and Ammals in Ireland, 2nd Edition. Dublin, An Foras Forbartha.

Phillips, S.J., Dudik, M. (2008): Modeling of species distributions with Maxent: new extensions and a comprehensive evaluation. Ecography 31: 161-175.

Phillips, S.J., Dudik, M., Schapire, R.E. (2004): A maximum entropy approach to species distribution modeling.
In: Machine Learning. Proceedings of the Twenty-first Century International Conference on Machine Learning. Brodley, C.E., Ed., Banff, Canada, ACM Press.

Phillips, S.J., Anderson, R.P., Schapire, R.E. (2006): Maximum entropy modeling of species geographic distributions. Ecol. Model. 190: 231-259.

Pilorge, H. (1987): Density, size structure, and reproductive characteristics of three populations of Lacerta vivipara (Sauria: Lacertidae). Herpetologica 43 (3): 345-356.

Quinn, G.P., Keough, M.J. (2004): Experimental Design and Data Analysis for Biologists. Cambridge, Cambridge University Press.

Strijbosch, H. (1988): Habitat selection of Lacerta vivipara in lowland environment. Herpetol. J. 1: 207-210.

Taylor, R.H.R. (1963): The distribution of amphibians and reptiles in England and Wales, Scotland and Ireland and the Channel Isles: a revised survey. Br. J. Herpetol. 3 (5): 95-115.

Usher, M.B. (1992): Management and diversity of arthropods in Calluna heathland. Biodivers. Conserv. 1: 63-79.

Received: November 4, 2009. Accepted: February 23, 2010. 